\title{
Methodology for assessing the rates of reproduction social infrastructure of agriculture
}

\author{
Tatiana Ivanova ${ }^{1}{ }^{*}$, Anatoly Saiganov ${ }^{2}$, Oleg Sorokin ${ }^{1}$, Elvira Kuznetsova ${ }^{1}$, and Svetlana \\ Petrova $^{1}$ \\ ${ }^{1}$ Chuvash State University named I.N. Ulyanov, Moskovsky prospect, 15, 428015 Cheboksary, \\ Russia \\ ${ }^{2}$ Republican Scientific Unitary Enterprise "Institute for System Research in Agroindustrial Complex \\ of the National Academy of Sciences of Belarus", Kazintsa Street, 103, 220108 Minsk, Belarus
}

\begin{abstract}
The article developed a methodology for assessing the rate of reproduction of the social infrastructure of agriculture. For this, a list of indicators has been defined that characterize the rural social infrastructure of the Russian Federation for 2009-2018; their analysis was carried out and index values were determined; formulas for calculating three integral indicators have been developed, reflecting the commissioning of objects of rural social infrastructure, communal services and areas equipped with communal networks; on their basis, the rates of reproduction of the social infrastructure in the industry were calculated; recommendations on the application of the obtained data are given.
\end{abstract}

\section{Introduction}

Social infrastructure is a set of engineering and social facilities that meet the needs of the population in labor, socio-political and spiritual activities, as well as in the sphere of family and everyday life, contributing to the consolidation of residents in a particular territory. When considering the social infrastructure of a village, the range of its facilities is territorially narrowed down to the framework of rural areas, and the "target audience" is represented by the rural population.

The purpose of the article is, based on statistical data on the main indicators of the social infrastructure of agriculture in the Russian Federation for 2010-2018, to develop a methodology for assessing the rate of its reproduction.

To achieve this goal, the following tasks must be solved: to determine the list of indicators characterizing the reproduction of the social infrastructure of agriculture in the Russian Federation; analyze them and bring them to index values; develop formulas for calculating three integral indicators (reflecting: commissioning of rural social infrastructure facilities, utilities and areas equipped with communal networks) and, on their basis, calculate the rate of reproduction of social infrastructure in the industry; to give recommendations on the application of the obtained data. In the course of the study, the

*Corresponding author: ivanovatv85@mail.ru 
following tools were used: analysis and synthesis, correlation and regression analysis, statistical and systemic approaches, index and integral methods.

\section{Materials and methods}

Analyzing foreign publications over the past five years [1-13] and, taking into account the absence of similar works on these issues in the Russian Federation (except for the author's [14-17]), we came to the conclusion that the research technologies used in them are based on only on analysis, which does not allow assessing the rate of their reproduction. In contrast to the presented publications, this paper proposes to use the index method with the derivation of integral indicators to substantiate the rate of reproduction of the social infrastructure of agriculture.

At the first stage of the assessment, a sample of the most significant criteria is formed to determine the rate of reproduction of the social infrastructure in agriculture. In an enlarged form, it includes many different indicators, but to simplify the calculations, seventeen (freely available on the Rosstat website) will be involved (Table 1), which will be reduced to an index value (in \% to the previous year) to make them accounting when calculating the integral indicator.

Table 1. Indicators characterizing the reproduction of social infrastructure agriculture of the Russian Federation for 2009-2018 [18].

\begin{tabular}{|c|c|c|c|c|c|c|c|c|c|c|}
\hline \multirow[t]{2}{*}{ Indicators } & \multicolumn{10}{|c|}{ Years } \\
\hline & 2009 & 2010 & 2011 & 2012 & 2013 & 2014 & 2015 & 2016 & 2017 & 2018 \\
\hline \multicolumn{11}{|c|}{ Commissioning of social infrastructure facilities in rural areas } \\
\hline $\begin{array}{l}\text { Residential buildings, } \\
\text { thousand } \mathrm{m} \text { of total area }\end{array}$ & 16132.5 & 14753.8 & 15570.7 & 15728.8 & 17535.3 & 21770.8 & 23370.7 & 21393.4 & 22025.7 & 20965.3 \\
\hline $\begin{array}{c}\text { Educational institutions, } \\
\text { student places }\end{array}$ & 23578 & 20260 & 21971 & 14406 & 24151 & 16768 & 23974 & 19544 & 26314 & 18628 \\
\hline $\begin{array}{c}\text { Preschool institutions, } \\
\text { places }\end{array}$ & 1742 & 3521 & 6476 & 6846 & 15570 & 26278 & 31452 & 13715 & 12492 & 9859 \\
\hline $\begin{array}{l}\text { Cultural institutions } \\
\text { club type, places }\end{array}$ & 13298 & 11358 & 11507 & 16396 & 10200 & 12517 & 10498 & 8536 & 16324 & 13238 \\
\hline Hospitals, beds & 1219 & 886 & 1625 & 1120 & 394 & 911 & 391 & 634 & 120 & 372 \\
\hline $\begin{array}{l}\text { Outpatient clinics, } \\
\text { visits per shift }\end{array}$ & 3305 & 2587 & 5896 & 5971 & 5121 & 8429 & 9556 & 8156 & 7119 & 10204 \\
\hline \multicolumn{11}{|c|}{ Commissioning of utility facilities, kilometers } \\
\hline Water supply networks & 1514.8 & 1522.0 & 1705.9 & 1368.0 & 1661.5 & 1750.4 & 1868.6 & 1088.7 & 932.2 & 921.1 \\
\hline Gas networks & 10882.1 & 11180.2 & 11907.3 & 12634.3 & 9129.8 & 8826.2 & 7173.2 & 6584.2 & 5749.2 & 6277.2 \\
\hline $\begin{array}{l}\text { 6-20 kV power } \\
\text { transmission lines }\end{array}$ & 6345.3 & 6300.4 & 6170.1 & 6039.9 & 5884.7 & 7444.1 & 4227.9 & 2928.3 & 3274.6 & 1192.3 \\
\hline Highways & 1426.2 & 1372.6 & 1020.4 & 668.1 & 419.4 & 356.3 & 384.8 & 421.7 & 686.7 & 865.4 \\
\hline \multicolumn{11}{|c|}{ The specific weight of the total area (in percent) equipped } \\
\hline Plumbing & 47 & 48 & 49 & 49 & 52 & 54 & 57 & 58 & 59 & 60 \\
\hline
\end{tabular}


Table 1. Continued

\begin{tabular}{|c|c|c|c|c|c|c|c|c|c|c|}
\hline $\begin{array}{c}\text { Water disposal } \\
\text { (sewerage) }\end{array}$ & 38 & 39 & 39 & 40 & 41 & 43 & 45 & 47 & 48 & 49 \\
\hline Heating & 59 & 60 & 61 & 61 & 64 & 65 & 67 & 68 & 62 & 63 \\
\hline Baths (shower) & 28 & 29 & 29 & 29 & 31 & 33 & 34 & 35 & 36 & 37 \\
\hline Gas (network, liquefied) & 74 & 75 & 74 & 74 & 73 & 73 & 74 & 74 & 73 & 74 \\
\hline Hot water supply & 25 & 25 & 26 & 27 & 28 & 30 & 33 & 34 & 42 & 42 \\
\hline $\begin{array}{c}\text { Floor-standing electric } \\
\text { stoves }\end{array}$ & 3 & 4 & 4 & 4 & 5 & 6 & 6 & 7 & 7 & 8 \\
\hline
\end{tabular}

Analyzing the data in Table 1 , it can be seen that the commissioning of residential buildings in rural areas of the Russian Federation increased from 2009 to 2018 by $4,832.8$ thousand $\mathrm{m}$ of the total area; preschool institutions - for 8117 student places, or 5.7 times; outpatient clinics - by 6899 visits per shift, or 3.1 times (which increased the workload on medical personnel). Also, during the analyzed period, there is an increase in the proportion of areas equipped with utilities.

For all other indicators - a decrease. Thus, the commissioning of general education institutions in rural areas decreased by 4950 student places; hospitals - by 847 beds, or 3.3 times; water supply networks - by 593.7 kilometers; gas networks - by 4604.9 kilometers; power lines - by 5153, or 5.3 times; highways - by 560.8 kilometers. For some indicators, there were no significant changes in different years. For example, on the commissioning of cultural institutions of the club type in rural areas and the specific weight of the total area equipped with gas.

At the second stage of the assessment, on the basis of Table 1, Table 2 is compiled, reflecting the index values of indicators affecting the reproduction of social infrastructure in agriculture of the Russian Federation in 2010-2018. The index analysis method allows you to aggregate a wide range of quantitative indicators of reproduction, which have different units of measurement and are not comparable with each other without standardizing values.

Table 2. Dynamics of changes in indicators characterizing the rates reproduction of the social infrastructure of agriculture in the Russian Federation for 2010-2018, in\% of the previous year.

\begin{tabular}{|c|c|c|c|c|c|c|c|c|c|c|c|}
\hline & \multicolumn{7}{|c|}{ Years } \\
\cline { 2 - 9 } & 2010 & 2011 & 2012 & 2013 & 2014 & 2015 & 2016 & 2017 & 2018 \\
\hline \multicolumn{2}{|c|}{ Indicators } & 91.5 & 105.5 & 101.0 & 111.5 & 124.2 & 107.3 & 91.5 & 103.0 & 95.2 \\
\hline $\begin{array}{c}\text { Index indicators reflecting the commissioning of social infrastructure facilities } \\
\text { of residential buildings }\end{array}$ & 85.9 & 108.4 & 65.6 & 167.6 & 69.4 & 143.0 & 81.5 & 134.6 & 70.8 \\
\hline $\begin{array}{c}\text { Index of change in the number } \\
\text { of educational institutions }\end{array}$ & 202.1 & 183.9 & 105.7 & 227.4 & 168.8 & 119.7 & 43.6 & 91.1 & 78.9 \\
\hline $\begin{array}{c}\text { Quantity change index } \\
\text { preschool institutions }\end{array}$ & 85.4 & 101.3 & 142.5 & 62.2 & 122.7 & 83.9 & 81.3 & 191.2 & 81.1 \\
\hline $\begin{array}{c}\text { Quantity change index } \\
\text { club-type cultural institutions }\end{array}$ & 72.7 & 183.4 & 68.9 & 35.2 & 231.2 & 42.9 & 162.1 & 18.9 & 310.0 \\
\hline Hospital change index & 78.3 & 227.9 & 101.3 & 85.8 & 164.6 & 113.4 & 85.3 & 87.3 & 143.3 \\
\hline $\begin{array}{c}\text { Quantity change index } \\
\text { outpatient clinics }\end{array}$ & & & & & & & & &
\end{tabular}


Table 2. Continued

\begin{tabular}{|c|c|c|c|c|c|c|c|c|c|}
\hline \multicolumn{10}{|c|}{ Index indicators reflecting the commissioning of communal facilities } \\
\hline $\begin{array}{l}\text { Water supply network change } \\
\text { index }\end{array}$ & 100.5 & 112.1 & 80.2 & 121.4 & 105.4 & 106.8 & 58.3 & 85.6 & 98.8 \\
\hline Gas network change index & 102.7 & 106.5 & 106.1 & 72.3 & 96.7 & 81.3 & 91.8 & 87.3 & 109.2 \\
\hline $\begin{array}{l}\text { Index of changes in power } \\
\text { transmission lines with a } \\
\text { voltage of } 6-20 \mathrm{kV}\end{array}$ & 99.3 & 97.9 & 97.9 & 97.4 & 126.5 & 56.8 & 69.3 & 111.8 & 36.4 \\
\hline Road change index & 96.2 & 74.3 & 65.5 & 62.8 & 85.0 & 108. & 109.6 & 162.8 & 126.0 \\
\hline \multicolumn{10}{|c|}{ Index indicators of areas equipped with public utilities } \\
\hline $\begin{array}{l}\text { Index of changes in areas } \\
\text { equipped with water supply }\end{array}$ & 102.1 & 102.1 & 100 & 106.1 & 103.8 & 105.6 & 101.8 & 101.7 & 101.7 \\
\hline $\begin{array}{l}\text { Index of changes in areas } \\
\text { equipped with drainage } \\
\text { (sewerage) }\end{array}$ & 102.6 & 100 & 102.6 & 102.5 & 104.9 & 104.7 & 104.4 & 102.1 & 102.1 \\
\hline $\begin{array}{l}\text { Index of changes in areas } \\
\text { equipped with heating }\end{array}$ & 101.7 & 101.7 & 100 & 104.9 & 101.6 & 103.1 & 101.5 & 91.2 & 101.6 \\
\hline $\begin{array}{l}\text { The index of changes in the } \\
\text { areas of equipped baths } \\
\text { (shower) }\end{array}$ & 103.6 & 100 & 100 & 106.9 & 106.5 & 103.0 & 102.9 & 102.9 & 102.8 \\
\hline $\begin{array}{l}\text { The index of changes in the } \\
\text { areas of equipped gas (network, } \\
\text { liquefied) }\end{array}$ & 101.4 & 98.7 & 100 & 98.6 & 100 & 101.4 & 100 & 98.6 & 101.4 \\
\hline $\begin{array}{l}\text { The index of changes in the } \\
\text { areas of equipped hot water } \\
\text { supply }\end{array}$ & 100 & 104 & 103.8 & 103.7 & 107.1 & 110 & 103.0 & 123.5 & 100 \\
\hline $\begin{array}{l}\text { Index of changes in areas } \\
\text { equipped with floor-standing } \\
\text { electric stoves }\end{array}$ & 133.3 & 100 & 100 & 125 & 120 & 100 & 116.7 & 100 & 114.3 \\
\hline
\end{tabular}

At the third stage of the assessment, based on the information in Table 2, using formula (1), an integral indicator is calculated reflecting the commissioning of social infrastructure facilities in the agriculture of the Russian Federation in 2010-2019, ( $I I_{S I F}$ ) (in points ), where $I I_{R B}$ - index of change in the number of residential buildings, $\%$; $I I_{E I}$ - index of change in the number of educational institutions, $\% ; I I_{P I}$ - index of change in the number of preschool institutions, $\%$; $I I_{C I}$ - index of change in the number of cultural institutions of club type, $\% ; I I_{H}$ - index of change in the number of hospitals, $\% ; I I_{O C}$ - index of change in the number of outpatient clinics, $\%$.

$$
I I_{S I F}=\sqrt[6]{I_{R B} * I_{E I} * I_{P I} * I_{C I} * I_{H} * I_{O C}}
$$

Similarly, based on the data in Table 2, an integral indicator is calculated reflecting the commissioning of communal facilities in the agriculture of the Russian Federation in 20102019, ( $I I_{C C F}$ ) (in points), where $I I_{W N}$ - index of changes in water supply networks, \%; $I I_{G N}$ - index of changes in gas networks, $\% ; I I_{L V}$ - index of changes in power transmission lines with a voltage of $6-20 \mathrm{kV}, \% ; I I_{R}$ - index of changes in roads, $\%$.

$$
I_{C C F}=\sqrt[4]{I_{W N} * I_{G N} * I_{L V} * I_{R}}
$$


To calculate the integral indicator of the commissioning of areas equipped with communal networks in the agriculture of the Russian Federation in 2010-2019, ( $\left(I_{C N}\right)$ (in points), formula 3 is proposed.

$$
I I_{C N}=\sqrt[7]{I_{W S} * I_{D(S)} * I_{H} * I_{B(S)} * I_{G} * I_{H W} * I_{F E S}}
$$

where $I I_{W S}$ - index of changes in areas equipped with water supply, \%; $I I_{D(S)}$ - index of changes in areas equipped with drainage (sewerage), \%; $I I_{H}$ - index of changes in areas equipped with heating, \%; $I I_{B(S)}$ - index of changes in areas equipped with baths (showers), \%; $I I_{G}$ - index of changes in areas equipped with gas (network, liquefied), \%; $I I_{H W}$ - index of changes in areas equipped with hot water supply, \%; $I I_{F E S}$ - index of changes in areas equipped with floor-standing electric stoves, $\%$.

At the fourth stage of the assessment, the values of formulas 1-3 are substituted into formula 4 to calculate an integral indicator characterizing the rate of reproduction of the social infrastructure of agriculture in the Russian Federation ( $I I_{\text {R.S.I. }}$ ), (in points), where $I I_{S I F}$ - an integral indicator reflecting the commissioning of social infrastructure facilities points; $I I_{C C F}$ - an integral indicator reflecting the commissioning of communal facilities, points; $I_{C N}$ - an integral indicator of the commissioning of areas equipped with utilities, points.

$$
I I_{R . S . I .}=\frac{I I_{S I F}+I I_{C C F}+I I_{C N}}{3}
$$

The values of the integral indicator characterizing the rate of reproduction of the social infrastructure of agriculture in the Russian Federation $I I_{\text {R.S.I. }}$ are entered in Table 3.

Table 3. Integral indicator of the rate of reproduction of social infrastructure agriculture of the Russian Federation for 2010-2018, in points.

\begin{tabular}{|l|c|c|c|c|c|c|c|c|c|}
\hline \multicolumn{1}{|c|}{ Indicators } & \multicolumn{7}{c|}{ Years } & & \\
\cline { 2 - 9 } & 2010 & 2011 & 2012 & 2013 & 2014 & 2015 & 2016 & 2017 & 2018 \\
\hline $\begin{array}{l}\text { Integral indicator of } \\
\text { commissioning social } \\
\text { infrastructure facilities }\end{array}$ & 95.8 & 144 & 94.2 & 96.3 & 137.6 & 95.3 & 84.6 & 85.8 & 111.4 \\
\hline $\begin{array}{l}\text { Integral indicator of } \\
\text { commissioning utility facilities }\end{array}$ & 99.6 & 96.5 & 85.9 & 85.6 & 102.3 & 85.4 & 79.8 & 108 & 83.9 \\
\hline $\begin{array}{l}\text { Integral indicator of } \\
\text { commissioning areas equipped } \\
\text { with public utilities }\end{array}$ & 105.9 & 100.9 & 100.9 & 106.5 & 106.1 & 103.9 & 104.2 & 102.5 & 103.3 \\
\hline $\begin{array}{l}\text { Integral indicator of the rate of } \\
\text { reproduction of the social } \\
\text { infrastructure of agriculture }\end{array}$ & 100.4 & 113.8 & 93.7 & 96.1 & 115.3 & 94.9 & 89.5 & 98.8 & 99.5 \\
\hline
\end{tabular}

\section{Results and discussion}

At the fifth stage of the assessment, based on the classification of reproduction rates in agriculture, proposed by T.V. Ivanova. (Table 4) and on the calculations performed, designations of the rates of reproduction of the social infrastructure of agriculture are introduced.

Table 4. Classification of reproduction rates in agriculture 


\begin{tabular}{|c|c|c|}
\hline $\begin{array}{c}\text { Pace range } \\
\text { reproduction, points }\end{array}$ & Type & Species \\
\hline \multicolumn{3}{|c|}{ Table 4. Contunued } \\
\hline $0.10-0.20$ & \multirow{5}{*}{ 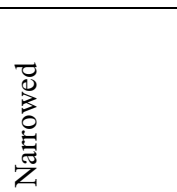 } & Extreme \\
\hline $0.21-0.40$ & & Disproportional \\
\hline $0.41-0.60$ & & Asymmetric \\
\hline $0.61-0.80$ & & Polarized \\
\hline $0.81-0.95$ & & Minimally narrowed \\
\hline $0.96-1.05$ & Simple & - \\
\hline $1.06-1.20$ & \multirow{5}{*}{ 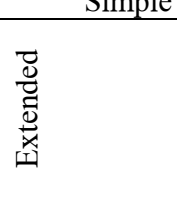 } & Minimum Extended \\
\hline $1.21-1.40$ & & Polarized \\
\hline $1.41-1.60$ & & Asymmetric \\
\hline $1.61-1.80$ & & Disproportional \\
\hline $1.81-1.96$ & & Extreme \\
\hline
\end{tabular}

Thus, in the analyzed period, the rates of reproduction of the social infrastructure of agriculture in the Russian Federation ranged from 89.5 points (minimum narrowed reproduction) in 2016 to 115.3 points (minimum expanded) in 2014. In this regard, the state needs to encourage organizations that invest in rural social infrastructure, since investing in the industry is one of the most important ways to improve the efficiency of agricultural production and reduce social tension in the countryside.

A systematic approach is required to successfully address the strategic objectives of increasing the economic potential of agriculture, the most important part of which is the implementation of measures to improve the level and quality of life in rural areas, the development of rural employment and full-fledged infrastructure development. Only the most attractive conditions for the material interest of a rural worker, a normal life close to city life, road communications, medical care, trade, and other social protection measures can prevent the outflow of the population from the countryside.

\section{Conclusions}

The actualization of certain social problems, the emergence of new ways of solving them in the context of changes in social relations, predetermine the transformation of people's claims to social services and related services. Obviously, local governments need to systematically study the transformation of the social needs of the population and its individual groups, as well as assess their satisfaction through the development of the social infrastructure of municipalities. Based on the assessment of social problems, it is necessary to make management decisions, form certain regulatory documents, programs, ensuring their real organizational, personnel, financial, institutional support.

Moreover, modern science offers the use of a two-level system of innovative technologies in the social sphere: 1) basic technologies, which include: targeted programs; priority national projects; foresight technologies; social standards; 2) functional technologies: performance-based budgeting; e-government; process technologies; social standards; outsourcing. Along with the traditional tools for the development of social infrastructure in rural areas, innovative technologies can be successfully applied. In many aspects, it is possible to use foreign experience, especially in relation to the practice of planning the development of the social sphere of the village, as well as the role of civil society institutions.

Thus, effective agricultural management largely depends on competent and timely government support, including through the creation of an appropriate social infrastructure. And the developed methodology for assessing the rate of reproduction of the social 
infrastructure of agriculture is a mathematical justification for the decisions made, representing one of the grounds for legislative and executive authorities in the development of socio-economic projects and programs.

\section{References}

1. S. Albeaik, M. Kaltenberg, M. Alsaleh, C.A. Hidalgo, Addendum to Improving the Economic Complexity Index (2017)

2. E.G. Bongiorno, A. Goia, Journal of Multivariate Analysis, 170 (2019)

3. S.A. Cole, W. Xiong, Annual Review of Economics, 9 (2017)

4. L. Hilty, B. Aebischer, ICT innovations for sustainability (2015)

5. D. Kosiorowski, J.P. Rydlewski, Centrality-oriented Causality-A Study of EU Agricultural Subsidies and Digital Developement in Poland (2019)

6. S.J. Lee, E.H. Lee, D.S. Oh, World Technopolis Review, 6(1) (2017)

7. Y. Lou, J. Bien, R. Caruana, J. Gehrke, Journal of Computational and Graphical Statistics, 25(4) (2016)

8. N.N. Minina, Achievements of science and technology of the agro-industrial complex, 32(1) (2018)

9. R. Njos, S.E. Jakobsen, Regional Studies, Regional Science, 3(1) (2016)

10. A.N. Stavtsev, G.A. Miroshnikov, RJOAS, 1(49) (2016)

11. A. Tacchella, D. Mazzilli, L. Pietronero, Nature Physics, 14(8) (2018)

12. M. Tahamipour, M. Mahmoudi, Macrothink Institute: Research in Applied Economics, 10(1) (2018)

13. D. Yoon, Journal of Science and Technology Policy Management, 8(2) (2017)

14. T.V. Ivanova, Scientific works of the Institute of Economics of the National Academy of Sciences of Azerbaijan, 4 (2017)

15. T.V. Ivanova, A.A. Ivanova, IOP Conf. Series: Earth and Environmental Science, 613 (2020)

16. V.N. Orlov, T.V. Ivanova, V.A. Arkhipova, I.P. Ivanitskaya, PbWOSCE-2018: Business technologies for sustainable urban development, E3S Web Conf., 110 (2019)

17. V.N. Orlov, T.V. Ivanova, S.A. Brechagova, N.N. Rumbayeva, IOP Conf. Series: Earth and Environmental Science, 433 (2020)

18. Agro-industrial complex of Russia in 2018: Statistical compilation (2019) 